\title{
The 'vicious cycle' of energy poverty and productivity: insights from 45 developing countries
}

\author{
Canh Phuc Nguyen ${ }^{1}$ (D) Thanh Dinh Su ${ }^{1}$ \\ Received: 1 April 2021 / Accepted: 25 May 2021 / Published online: 29 May 2021 \\ (C) The Author(s), under exclusive licence to Springer-Verlag GmbH Germany, part of Springer Nature 2021
}

\begin{abstract}
This study is the first proper attempt to examine the influence of energy poverty on productivity. Specifically, the study investigates the effects on the level and convergence of total factor productivity of no access to clean fuels and technologies for cooking; no access to electricity in the total population; no access to electricity in the rural population; no access to electricity in the urban population; non-renewable electricity production; and non-renewable electricity consumption. The study examines a global sample of 45 developing countries from 2002 to 2017 and offers three empirical analysis findings. First, the mutual causalities between the five dimensions of energy poverty and total factor productivity are shown by a non-Granger causality test for panel data, except one-direction causality from no access to clean fuels and technologies for cooking to total factor productivity convergence, which hints a 'vicious cycle' of two variables. Second, the two-step system generalised method of moments estimates show significant negative impacts of no access to clean fuels and technologies for cooking and the three variables of no access to electricity on total factor productivity. In contrast, the production and consumption of non-renewable electricity appear to have significant positive effects. Third, the three-stage least squares estimates provide statistical evidence that the effects of energy poverty on total factor productivity are transmitted through human capital accumulation, Internet usage, and the shadow economy.
\end{abstract}

Keywords Productivity $\cdot$ Total factor productivity $\cdot$ Energy poverty $\cdot$ Human capital $\cdot$ Internet usage $\cdot$ Developing countries

JEL Classification $\mathrm{O} 13 \cdot \mathrm{Q} 43 \cdot \mathrm{E} 24 \cdot \mathrm{J} 24 \cdot \mathrm{O} 17 \cdot \mathrm{O} 40 \cdot \mathrm{L} 86 \cdot \mathrm{Q} 01$

\section{Introduction}

Against the backdrop of climate change and sustainable development aims, energy poverty (EP) emerges as an important issue that has mostly been ignored in recent decades (Awaworyi Churchill et al. 2020; González-Eguino 2015). Several previous studies have briefly mentioned the linkage between EP and productivity (e.g. see Sovacool et al. (2012),

Responsible Editor: Roula Inglesi-Lotz

Canh Phuc Nguyen

canhnguyen@ueh.edu.vn

Thanh Dinh Su

dinhthanh@ueh.edu.vn

1 School of Public Finance, University of Economics Ho Chi Minh City, 59C Nguyen Dinh Chieu, District 3, Ho Chi Minh 700000, Vietnam
Kaygusuz (2011)); however, there have been few attempts to investigate the influence of EP on productivity. This study endeavours to examine the effects of EP on productivity in a global sample of developing countries.

The literature shows that people experiencing EP are forced to expend more time collecting water and local energy resources (Chevalier and Ouédraogo 2009) and spend a greater proportion of their income on energy (Groh 2014). Most detrimentally, EP is documented as the cause of degradation of individual well-being and health (e.g. see Kose (2019), Llorca et al. (2020)). Recently, Amin et al. (2020) find that EP causes a decrease in economic development in both the short- and long-run in a sample of seven South Asian countries from 1995 to 2017. Meanwhile, developing countries have attempted different ways to improve productivity growth to overcome the middle-income trap (Glawe and Wagner 2019). Governments in these countries have invested in education, health, and social welfare spending (e.g. see Fleisher et al. (2010), Jones and Romer (2010)); however, the results have 
not been entirely as expected (Khor et al. 2016). More importantly, developing countries face severe effects of EP (Chevalier and Ouédraogo 2009) along with low productivity (Bresnahan et al. 2016; Li and Tanna 2019).

Therefore, understanding the influence of EP on productivity might help to explain the low pace of labour productivity in developing countries. The study also explains the channel through which EP affects economic development, namely labour productivity. The results of the study are also important for policymakers aiming at sustainable economic development, a topic that has gained a great deal of attention in the context of the increasing intensity and complexity of economic activities (Wang et al. 2021).

This study applies empirical analysis to a sample of 45 developing countries from 2002 to 2017, based on the availability of data. Six different proxies of EP are used to give an overall view of the issue under discussion: no access to clean fuels and technologies for cooking; no access to electricity in the total population; no access to electricity in the rural population; no access to electricity in the urban population; nonrenewable electricity production; and non-renewable electricity consumption. Total factor productivity (TFP) is the most popular concept/proxy of productivity (Mastromarco and Zago 2012). Thus, the TFP level at constant national prices and the TFP level at current PPP (USA=1) are used to proxy for TFP level and TFP convergence, respectively. Estimates of the effects of EP on TFP are controlled with capital stock, human capital accumulation, trade openness, and FDI net inflows. The non-Granger causality test of Dumitrescu and Hurlin (2012) is first applied to examine causality between each proxy of EP and TFP level/convergence. The two-step system generalised method of moments (GMM) of Blundell and Bond (1998) is employed to estimate the influence of EP on TFP level/convergence to deal with potential endogeneity, while the sequential (two-stage) estimation of a linear paneldata model (SELPDM) of Kripfganz (2017) is used for robustness checks. The results show mutual causality between five of the six proxies of EP and both the TFP level and TFP convergence, except for one-direction causality from no access to clean fuels and technologies for cooking to TFP convergence. Notably, no access to clean fuels and technologies for cooking/no access to electricity (in the total, rural, and urban populations) has significant negative impacts on TFP level/convergence, while both production and consumption of non-renewable electricity have significant positive impacts. The results indicate that EP causes productivity reductions in developing countries, while non-sustainable electricity production and consumption contribute positively to productivity.

Based on these findings, this study goes further to examine the transmission of EP effects on productivity. The literature mostly agrees on some common determinants of TFP, such as technology progress (Baum et al. 2018); capital accumulation
(Hein 2012); human capital accumulation (Männasoo et al. 2018); institutional quality (d'Agostino and Scarlato 2019); economic integration (Defever et al. 2020; Demir and Duan 2018); and informal economic activities (Chancellor and Abbott 2015). Following this theoretical framework, the study proposes and examines three possible channels of EP effects on productivity: human capital, technology development, and the shadow economy. ${ }^{1}$ The study does not consider channels through capital stock, institutional quality, or economic integration, since EP may not have an important impact on these factors.

Three-stage least squares (3SLS) estimates are applied for three system equations of EP, with human capital, Internet usage (a proxy of technology development), and the shadow economy. A two-stage least squares (2SLS) estimate is used for robustness checks. The results show that the effects of EP on TFP level/convergence are transmitted through human capital accumulation, Internet usage, and informal economic activities.

Specifically, no access to clean fuels and technologies for cooking and no access to electricity (in the total, rural, and urban populations) have significant negative impacts on human capital, while non-renewable electricity production and consumption have significant positive impacts. Meanwhile, human capital has a significant positive impact on TFP lev$\mathrm{el} /$ convergence. Similar evidence is found in the case of Internet usage. Regarding the channel of the shadow economy, no access to clean fuels and technologies for cooking, no access to electricity in the rural population, and non-renewable electricity production have significant positive impacts on the shadow economy. However, non-renewable electricity consumption has a significant negative impact on the shadow economy. Meanwhile, the shadow economy is found to have significant negative impacts on TFP level/convergence. Overall, the results imply that EP, in terms of access to clean fuels and technologies for cooking and access to electricity, detrimentally affects human capital/Internet usage, which then causes a reduction in TFP level/convergence. Additionally, usage of non-renewable electricity is likely to contribute positively to human capital accumulation/Internet development, which then diminishes TFP level/convergence. Lastly, EP may lead to increases in informal economic activities, thereby reducing TFP level/convergence.

The study makes a twofold contribution to the literature. First, the study extends the literature on EP to include the consequence for productivity. The results show a negative impact of EP on TFP, which highlights an important economic consequence of EP besides other consequences described in the literature, such as reductions in individual well-being (González-Eguino 2015; Sovacool 2012) and increases in

\footnotetext{
${ }^{1}$ The terms shadow economy, informal economic activities, and unofficial economic activities are used interchangeably.
} 
income inequality (Nguyen and Nasir 2021). Second, the study adds new global evidence to the current literature on the linkage between EP and economic development. Previous studies (e.g. Chevalier and Ouédraogo (2009)) mention that EP is a harmful factor to economic growth, but there are likely no studies on the channels of these influences. This study reveals that EP causes a reduction in labour productivity, which might then lead to a decrease in economic growth. This finding has important implications for policymakers aiming at sustainable economic development. Notably, the study carries out a detailed analysis on the channels through which EP decreases TFP, namely human capital, technology development, and the shadow economy. This finding is a significant contribution to the literature on productivity and growth, especially the mechanism and drivers of productivity and economic growth.

The remainder of this paper is structured as follows. The next section is a short literature review on EP and productivity. "Methodology and data" introduces the methodology and data. The results are presented and discussed in "Results and discussion". The final section is the conclusion and includes policy implications.

\section{Literature review and hypothesis construction}

Extensive literature has focused on the determinants of TFP, with several empirical studies examining different levels, i.e. firm level (Figal Garone et al. 2020), sector level (Papaioannou 2018), national level (Viet Nguyen et al. 2019), and cross-country level (Rath et al. 2019). However, there is still debate around obstacles to and challenges of TFP growth and long-run economic development in developing countries (e.g. see Glawe and Wagner (2019)).

Governments in developing countries have focused on human capital development through public investment in education and health systems (e.g. see Engelbrecht (2002)). However, the results are not always as expected (Ahsan and Haque 2017). Other studies mention potential drivers or the association between determinants of TFP. Miller and Upadhyay (2000) reveal that the association between human capital and trade openness has a positive impact on TFP in developing countries. Adetutu and Ajayi (2020) conducted a study on agricultural productivity in 30 Sub-Saharan African countries from 1981 to 2011, and noticed that both domestic and foreign R\&D spending contribute significantly to agricultural TFP growth. Recently, Figal Garone et al. (2020) show that aggregate productivity in Latin America and the Caribbean is still low, while firms' productivity reflects significant differences across industries, which persist over time.
In energy economics, energy is perceived as having an overriding role in production and consumption (Canh et al. 2020a), and then economic development (Le and Nguyen 2019). In particular, EP is emphasised as an important facet of sustainable development (Awaworyi Churchill and Smyth 2020). Despite heated debate on the definition of EP, such as EP versus fuel poverty (González-Eguino 2015), EP is unanimously referred to as the inability of households to meet domestic energy needs (Thomson et al. 2016). The literature also proposes three main approaches to measuring EP, namely technological threshold, physical threshold, and economic threshold (Pachauri and Spreng 2011). The empirical literature uses different proxies of EP depending on the context and availability of data, such as access to different types of energy, levels of energy consumption (Pachauri et al. 2004), access to modern energy fuels (Pereira et al. 2010), and access to modern technologies for cooking (Sesan 2012). Recent studies (Awaworyi Churchill and Smyth 2020; Awaworyi Churchill et al. 2020; Kose 2019) agree on access to clean fuels and technologies for cooking, and access to electricity, as remarkable proxies of EP (González-Eguino 2015).

Furthermore, scholars pay special attention to the severity and consequences of EP. Chevalier and Ouédraogo (2009) indicate that nearly 1.6 billion people have no access to modern energy fuels, while Sovacool et al. (2012) add that nearly 2.4 billion people across the globe are without access to electricity, or have limited and unstable access to electricity networks. Above all, EP is seen as a severe issue in several developing countries, such as India (Jain 2010), South Africa (Monyei and Adewumi 2017), and Brazil (Giannini Pereira et al. 2011). The issue of EP in developing countries has been further addressed as a matter of urgency as a result of the COVID-19 pandemic (Goyens 2020). Moreover, the literature shows that EP leads to socioeconomic-environmental consequences that pose challenges and obstacles to sustainable development (Awaworyi Churchill et al. 2020; Rodriguez-Alvarez et al. 2019). Sovacool et al. (2012), for instance, finds that EP causes deforestation, land-use changes, and greenhouse gas emissions, while Bouzarovski (2014) notes that EP may be linked to vulnerability. There have been some studies on the link of EP with productivity (Awaworyi Churchill and Smyth 2020). For example, Kaygusuz (2011) mentions the 'vicious circle' of EP, where low demand for modern energy prevents power providers from setting up the infrastructure to supply the fuels, while EP prevents workshop owners and farmers from productivity improvements and income, which then results in low demand. Sovacool et al. (2012) adds that the EP and productivity link should be among four classes of benefit in alleviating EP in developing countries. However, there is no proper theoretical explanation or empirical investigation into this link, and particularly into the channels of the effects. 
EP has consequences not only for people's health and individual well-being (González-Eguino 2015; Sovacool 2012) but also for economic development (Chevalier and Ouédraogo 2009). Specifically, Chevalier and Ouédraogo (2009) raise the issue that people experiencing EP have to spend more time collecting water and local energy resources. Kaygusuz (2010) explains that EP can disrupt people's living and economic activities, while Groh (2014) notes that people with EP have to spend a larger proportion of their income on energy consumption. Okushima (2016) finds that EP is likely the cause of decreased income, especially among lower income and vulnerable households. Several recent studies (e.g. Thomson et al. (2017), Rodriguez-Alvarez et al. (2019), Kose (2019)) find that EP can exert negative impacts on individuals' wellbeing and physical/mental health, with the consequence that EP might ruin productivity. This study therefore proposes the first hypothesis:

\section{H1: EP causes a reduction in productivity.}

In the literature, human capital accumulation is argued as one of the main drivers of productivity (Chang et al. 2016), while EP is found to have negative impacts on people's living standards, health, and income (Chevalier and Ouédraogo 2009; Llorca et al. 2020). Thus, EP may lead to a deterioration in human capital since people have to spend more time collecting basic materials for living (Chevalier and Ouédraogo 2009). EP might also prevent people from accessing education to improve human capital and skills. In summary, EP may cause the degradation of human capital, resulting in productivity reduction. The second hypothesis is thus formed as follows:

\section{H2: The negative impact of EP on productivity is trans-} mitted through its effect on human capital.

Technologies are also documented as being important drivers of productivity (Edquist and Henrekson 2017). The boom in the Internet in recent decades is regarded as a main driver of productivity through knowledge spillover and innovation (Hanna et al. 2017). However, the existence of EP means a lack of modern energy services such as electricity (Thomson et al. 2016), while electricity is the basic condition for ICT development, especially Internet usage. Therefore, EP might also be a barrier to technology development, such as use of the Internet (Muller 2009). As a result, EP may lead to the under-development of the Internet, which then causes a decrease in productivity. Thus, the third hypothesis can be proposed:

H3: The negative impact of EP on productivity is transmitted through its effect on technology development.
Recent studies suggest the distorting effects of informal economic activities on productivity (Chancellor and Abbott 2015). Meanwhile, the literature shows that people with EP have to spend more time on informal sector activities such as collecting water and local energy resources (Chevalier and Ouédraogo 2009). They also have to spend a larger proportion of their income on energy (Groh 2014), and thus are likely to work in the shadow economy to avoid taxation of their remaining income (Canh and Dinh Thanh 2020). Overall, EP may cause growth in the shadow economy that may result in the distortion of productivity (Chancellor and Abbott 2015). Hence, the fourth hypothesis can be proposed:

H4: The negative impact of EP on productivity is transmitted through its effect on the shadow economy.

There are other drivers of productivity which can transmit the effects of EP to productivity, e.g. capital accumulation (Howitt and Aghion 1998) or economic integration (Defever et al. 2020; Demir and Duan 2018). However, the current literature does not show the links of EP with capital investment, institutional quality, or economic integration. Capital formation is usually executed by large firms and high earners, who are unlikely to experience EP. Trade activities and FDI inflows are also likely economic activities of international and large firms that would be less linked with EP. Therefore, the study does not consider the channels of EP effects on productivity through these factors.

\section{Methodology and data}

\section{Empirical models}

Based on what is commonly used in the specialised literature (e.g. see Ashraf et al. (2016), Demir and Duan (2018)), we employ the baseline model of productivity for developing countries, as follows:

$$
\begin{aligned}
\operatorname{TFP}_{i t}= & \alpha_{0}+\alpha_{1} \operatorname{Cap}_{i t}+\alpha_{2} H C_{i t}+\alpha_{3} \text { Trade }_{i t}+\alpha_{4} F D I_{i t} \\
& +\varepsilon_{i t}
\end{aligned}
$$

in which $i$ and $t$ are country $i$ at year $t$;FP is the total factor productivity, which proxies for productivity; Cap is the capital accumulation; $H C$ is the human capital accumulation; Trade is the trade openness; and FDI is the FDI net inflows.

To examine the influences of EP on productivity, EP is then added as an augmented driver of TFP, as follows:

$$
\begin{aligned}
\operatorname{TFP}_{i t}= & \alpha_{0}+\alpha_{1} \text { Cap }_{i t}+\alpha_{2} \mathrm{HC}_{i t}+\alpha_{3} \text { Trade }_{i t}+\alpha_{4} F D I_{i t} \\
& +\alpha_{5} E P_{i t}+\varepsilon_{i t}^{\prime}
\end{aligned}
$$


In the second stage of the investigation, the channels of EP effects on productivity are emphasised; specifically, there are several steps to be taken to realise this procedure.

First, the study examines the effects of EP on productivity through the channel of human capital. To do this, the study builds a system equation of productivity and human capital. The control variables of productivity are retained as in Eq. (1). The function of human capital is kept simple, with several main control variables from previous literature, including income level (Income), and trade openness (Trade) (Blanchard and Olney 2017). EP is then added as a driver of human capital accumulation. The system equation for TFP and human capital accumulation is as follows:

$$
\left\{\text { TFP }_{i t}=\alpha_{0}+\alpha_{1} \text { Cap }_{i t}+\alpha_{2} H C_{i t}+\alpha_{3} \text { Trade }_{i t}+\alpha_{4} F D I_{i t}+\varepsilon_{i t}\right.
$$

Second, the study analyses the effects of EP on productivity through the channel of technology development. The system equation of productivity and technology development is built, comprising (i) technology development, proxied by Internet usage, which is added to Eq. (1) to form the equation of productivity; and (ii) the equation of Internet usage, including income level (Income) and institutional quality (Inst) as main control variables, as proposed in previous literature (Beilock and Dimitrova 2003; Manlove and Whitacre 2019). EP is then added to the equation of Internet usage as an explanatory factor. The system equation of TFP and Internet usage (Internet) is as follows:

$\left\{\right.$ TFP $_{i t}=\alpha_{0}+\alpha_{1}$ Cap $_{i t}+\alpha_{2} H C_{i t}+\alpha_{3}$ Trade $_{i t}+\alpha_{4} F D I_{i t}+\alpha_{5}$ Internet $_{i t}+\varepsilon_{i t}$ $\left\{\right.$ Internet $_{i t}=\beta_{0}+\beta_{1}$ Income $_{i t}+\beta_{2}$ Inst $_{i t}+\beta_{3} E P_{i t}+\partial_{i t}$

Lastly, the effects of EP on TFP through the channel of the shadow economy are examined through the following system equation. The equation of TFP is retained as in Eq. (1), with the inclusion of the shadow economy as an explanatory variable. The function of the shadow economy includes as control variables, as used in previous literature: income level (Income); institutional quality (Inst); and financial development (FD) and its square term (Canh and Thanh 2020; Canh et al. 2020b). EP is then added as an explanatory factor of the shadow economy. The system equation of TFP and shadow economy $(S E)$ is as follows:

$\left\{\begin{array}{c}T F P_{i t}=\alpha_{0}+\alpha_{1} \text { Cap }_{i t}+\alpha_{2} H C_{i t}+\alpha_{3} \text { Trade }_{i t}+\alpha_{4} F D I_{i t}+\alpha_{5} S E_{i t}+\varepsilon_{i t} \\ S E_{i t}=\lambda_{0}+\lambda_{1} \text { Income }_{i t}+\lambda_{2} \text { Inst }_{i t}+\lambda_{3} F D_{i t}+\lambda_{4} F D^{2_{i t}}+\lambda_{5} E P_{i t}+\partial_{i t}\end{array}\right.$

\section{Data and measurement of variables}

Among the three primary methods of EP measurement (see Pachauri and Spreng (2011)), González-Eguino (2015) notes that the technological threshold is favoured over the physical and economic thresholds in studies using cross-country samples due to its capability of comparison. Furthermore, the 'basic necessities' in the physical threshold method are different across countries, while differences in purchasing power and energy prices, or difficulty in maintaining adequate temperature levels across countries, causes the issue of the economic threshold method. Most previous studies agree that access to clean fuels and modern technologies for cooking and access to electricity (based on the technological threshold method) are the most appropriate measures of EP (Awaworyi Churchill and Smyth 2020; Awaworyi Churchill et al. 2020). Therefore, this study chooses access to clean fuels and technologies for cooking and access to electricity as the main proxies of EP.

Regarding access to electricity, to perform a more detailed analysis, we use three variables: access to electricity in the total population, access to electricity in the rural population, and access to electricity in the urban population. Since the above four variables have maximum values at $100 \%$ and minimum values at $0 \%$, and increases in them signify lower levels of EP, we transform them by subtracting their values from 100 to form no access to clean fuels and technologies for cooking $(E P 1)$, no access to electricity in the total population $(E P 2)$, no access to electricity in the rural population (EP3), and no access to electricity in the urban population (EP4), respectively, in the empirical analysis. This transformation helps account for the fact that any increase in these proxies means increases in EP.

This study takes a further step, to use additional proxies for EP as our novel contribution. The literature shows that EP is one of the substantial facets of sustainable development (Awaworyi Churchill and Smyth 2020), while the literature suggests considering sustainable consumption and production of energy in the progress of sustainable development (UN 2019). Therefore, we gather the renewable electricity output (\% of total electricity output) and renewable energy consumption (\% of total final energy consumption) from the World Development Indicators (WDI), and then transform them also by subtracting their values from 100 to form non-renewable electricity output (EP5), and non-renewable energy consumption $(E P O)$, as further proxies of EP. These two proxies represent the sustainability of electricity production and consumption, respectively, which means that increases in these variables imply a degradation of energy sustainability, or an increase in EP, from the perspective of sustainability. Six proxies of EP are assembled and calculated from the World Development Indicators database of the World Bank (WDI, version 2020), where data is largely available from the $2000 \mathrm{~s}$ to 2017 for most developing countries. ${ }^{2}$

\footnotetext{
${ }^{2}$ The data of no access to clean fuels and technologies for cooking are available to 2016; the data on renewable electricity production/consumption are available to 2015. For more details, see Table 1 .
} 
In terms of productivity, the study obtains TFP indices from the Penn World Table (PWT-latest version 9.1.) of Feenstra et al. (2015). In the PWT, there are two appropriate variables for the TFP level (TFP) and TFP convergence $(T F P c)$, i.e. TFP at constant national prices $(2011=1)$ and TFP level at current PPPs (USA=1), respectively. According to Feenstra et al. (2015), TFP at constant national prices $(2011=1)$ provides a comprehensive empirical analysis of the growth of productivity over time in each country and thus is used to proxy for the TFP level. The TFP level at current PPPs $(U S A=1)$ is ideal for comparing productivity levels across countries each year, and is therefore appropriate to study TFP convergence (towards the TFP level of the leading economy, the USA). ${ }^{3}$

Regarding control variables, real capital stock and real GDP are collected from the PWT, and the percentage of capital stock to real GDP (Cap) is calculated to proxy for capital accumulation. The human capital index is also collected from the PWT, and its natural logarithm is taken to proxy for human capital accumulation $(H C)$. Trade as a percentage of GDP (Trade) and FDI net inflows as a percentage of GDP $(F D I)$ are obtained from the WDI to proxy for trade openness and FDI inflows, respectively. Real GDP per capita is collated from the WDI with logarithm taken to proxy for income level (Income). Individuals using the Internet, as a percentage of the population, is collected from the WDI to proxy for Internet usage (i.e. technology development). Six institutional indicators, i.e. control of corruption, government effectiveness, regulatory quality, rule of law, political stability and absence of violence, and voice and accountability, are gathered from the Worldwide Governance Indicators database (WGI - World Bank), and their means are then calculated to proxy for institutional quality (Inst). The overall financial development index is recruited from the new database of financial development from the IMF (FD-IMF) to proxy for financial development $(F D)$. Lastly, the shadow economy as a percentage of GDP is collected from the study of Medina and Schneider (2018), supported by the IMF, to proxy for the shadow economy $(S E)$.

While the data for the proxies of EP is largely available from 2000 to 2017 , the availability of other data is likely to be similar; for instance, institutional indicators are available annually from 2002 to 2018. Interestingly, data on Internet usage is mostly available from the 2000 s, which is in line with the development of the Internet across the globe in recent decades (Lapatinas 2019). Therefore, the period of 20022017 is chosen as the best timespan for the empirical investigation.

\footnotetext{
${ }^{3}$ For more details on the measures and advantages of these TFPs, see Feenstra et al. (2015). Despite certain drawbacks to using these variables, they are the best available measures of TFP level and TFP convergence.
}

After defining the period of analysis, the study collects all variables and matches them together. The sample is then processed by dropping all advanced economies (mostly highincome economies) to narrow down to a sample of developing countries. This process is appropriate since most advanced economies have typically $100 \%$ of the population with access to clean fuels and technologies for cooking or access to electricity; also, advanced countries are likely experiencing no EP or there is negligible space for improvements in EP. The sample includes more than 130 developing countries, but many countries have missing data in the main variables (proxies of EP, TFP, human capital index, shadow economy, and Internet usage). The study then eliminates countries in the sample with missing data. Hence, the final sample comprises 45 developing countries (see Table A1, Appendix, for the list of countries).

Table 1 presents the variables, definitions, calculations, sources, data availability, and data descriptions. Table 2 reports the unconditional correlations between the main variables. Table 2 shows significant negative correlations between EP1, EP2, and EP3, and both the TFP level and TFP convergence. EP4 (no access to electricity in the urban population) has an insignificant positive correlation with the TFP level, but a significant negative correlation with TFP convergence. Both EP5 and EP6 have significant positive correlations with both the TFP level and TFP convergence. The results imply that there are likely negative linkages between no access to clean fuels and technologies for cooking/no access to electricity and productivity and positive linkages between non-renewable electricity production/consumption and productivity.

Figure 1 shows some further EP-related facts in our sample. Observations show that most developing countries have decreasing trends in EP from both the aspect of no access to clean fuels and technologies for cooking (Fig. 1a) and no access to electricity in the total population (Fig. 1b). However, some cases show increasing trends, such as Zimbabwe; other cases do not show much change in EP, such as Burundi, Central African Republic, Lao PDR, and Mozambique. Figure 2 illustrates the trends in the TFP level (Fig. 2a) and TFP convergence (Fig. 2b). For most countries, it shows an increasing trend in the TFP level, but TFP convergence varies across countries. This result is likely consistent with evidence from previous studies (Bai et al. 2019) that productivity may not be as expected in the traditional theory for convergence, highlighting the need to understand the dynamics of TFP/productivity beyond the traditional drivers.

\section{Econometrical estimates}

The study firstly recruits the non-Granger causality test by Dumitrescu and Hurlin (2012) for panel data to examine causal linkages between each variable of EP and TFP 
level/convergence. Then, the study estimates the effects of EP on TFP level/convergence following Eq. (2). Since there are possible mutual linkages between EP and TFP, and this study focuses on the impacts of EP on TFP, we have to control for endogeneity due to the possible feedback effects from TFP on EP. In the econometrics literature, Anderson and Hsiao (1982) propose using the first-difference method to solve the endogeneity in panel data. The GMM estimator is then developed by Arellano and Bond (1991) as a more efficient estimate than the first-difference method. However, the GMM estimate of Arellano and Bond (1991) is blamed for the problem of asymptotic and considerable bias in unbalanced panel data (Roodman 2006), which is the form of our data. Arellano and Bover (1995) developed the system GMM estimate, extended by Blundell and Bond (1998) to reduce this bias, which is the two-step system GMM (Roodman 2009). Therefore, this study uses the two-step system GMM as the main estimate to deal with the endogeneity in panel data unbalanced with a short time period. In applying the two-step system GMM, the study includes year and area, ${ }^{4}$ and income group, ${ }^{5}$ into instrumental variables to deal with any possible endogeneity caused by the fixed effects of year, region, and income level. Furthermore, the study employs a recent estimate, developed based on the twostep system GMM, and sequential (two-stage) estimation of linear panel-data model (Kripfganz 2017), for robustness testing. In such estimation, we add control variables one by one to check for sensitivity of the results. ${ }^{6}$

Next, to examine the channels of EP effects on TFP following Eqs. (3), (4), and (5), the study uses the three-stage least squares (3SLS) estimator (Belsley 1988) for system equation estimates. The 3 SLS is particularly recommended as an appropriate estimate for the case of system equation (Zellner and Theil 1992). The study applies two-stage least squares (2SLS) for robustness checks.

\section{Results and discussion}

\section{Energy poverty and TFP level/convergence: Granger causality evidence}

The results of non-Granger causality tests for each proxy of EP with the TFP level and TFP convergence are reported in Table 3. The results show that all proxies of EP have significant causality on TFP level/convergence. In return,

\footnotetext{
$\overline{4}$ There are six areas in our sample: Europe and Central Asia; East Asia and Pacific; South Asia; the Middle East and North Africa; Sub-Saharan Africa; Latin America and the Caribbean.

5 There are three income levels in our sample: low-income, lower-middleincome, and upper-middle-income.

${ }^{6}$ The results can be provided on request.
}

the TFP level has significant causality on all proxies of EP, while TFP convergence has significant causality on most proxies of EP, excluding the case of no access to clean fuels and technologies for cooking. The result implies that there are likely mutual causalities between EP and productivity, and further supports the argument for the 'vicious circle' of EP in Kaygusuz (2011). The next subsection presents in detail the results of the two-step system GMM estimate for the impacts of EP on productivity.

\section{Effects of energy poverty on TFP level/convergence}

Before measuring the influences of EP on the TFP level and TFP convergence, the study checks for multicollinearity among the independent variables by estimating the variance inflation factor (VIF). The results in Table A2, Appendix, show that all VIF values are much lower than 10 , which indicates that there is no multicollinearity among independent variables. The twostep system GMM estimates are then applied and the results are presented in Table 4, showing that the results of the $\operatorname{AR}(2)$ test and Hansen test are statistically insignificant, implying that the two-step system GMM estimates are consistent and unbiased (Roodman 2009). The results of robustness testing by SELPDM estimates are reported in Table A3 Appendix, showing robust results generated by the two-step system GMM.

Table 4 shows that no access to clean fuels and technologies for cooking (EP1), no access to electricity in the total population (EP2), and no access to electricity in the rural population $(\mathrm{EP} 3)$ have significant negative impacts on the TFP level (TFP) and TFP convergence $(T F P c)$. No access to electricity in the urban population has a significant negative impact on TFP convergence and an insignificant negative impact on the TFP level. These results mean that increases in EP would reduce the TFP level and TFP convergence alike. That is, EP is a negative factor for the growth of productivity and the convergence of productivity of developing countries towards the level of advanced countries. The results are likely novel in providing strong empirical evidence for the negative impact of EP on productivity in developing countries, which is relatively consistent with the expectation from previous studies (e.g. Kaygusuz (2011) and Sovacool et al. (2012)).

Non-renewable electricity production (EP5) and nonrenewable electricity consumption (EP6) have significant positive impacts on both the TFP level and TFP convergence, which means that the production or consumption of non-renewable electricity would have increasing effects on TFP level/convergence in developing countries. This finding is in line with an extensive body of evidence that the increasing use of fossil fuels in the progress of 
Table 1 Variables, definitions, calculations, sources, time availability, and data descriptions

\begin{tabular}{|c|c|c|c|c|c|c|c|c|c|}
\hline Variable & Definition & Calculation & Source & Availability & Obs & Mean & S.D. & Min & Max \\
\hline TFP & TFP level & TFP at constant national prices $(2011=1)$ & $\begin{array}{l}\text { PWT } \\
9.1\end{array}$ & $1970 s-2017$ & 720 & 1.00 & 0.10 & 0.50 & 1.67 \\
\hline TFPc & TFP convergence & TFP level at current PPPs $(\mathrm{USA}=1)$ & $\begin{array}{l}\text { PWT } \\
9.1\end{array}$ & 1970s-2017 & 720 & 0.49 & 0.18 & 0.10 & 1.11 \\
\hline EP1 & Energy poverty 1 & $\begin{array}{l}\text { No access to clean fuels and technologies for cooking (\% of } \\
\text { population) }\end{array}$ & WDI & $2000 s-2016$ & 675 & 55.08 & 33.89 & 1.60 & 99.81 \\
\hline EP2 & Energy poverty 2 & No access to electricity ( $\%$ of population) & WDI & $2000 \mathrm{~s}-2017$ & 718 & 35.47 & 31.50 & 0.00 & 96.79 \\
\hline EP3 & Energy poverty 3 & No access to electricity (\% of rural population) & WDI & 2000s-2017 & 682 & 47.06 & 36.04 & 0.00 & 99.98 \\
\hline EP4 & Energy poverty 4 & No access to electricity (\% of urban population) & WDI & $2000 s-2017$ & 718 & 17.56 & 20.65 & 0.00 & 83.27 \\
\hline EP5 & Energy poverty 5 & Non-renewable electricity output ( $\%$ of total electricity output) & WDI & $2000 s-2015$ & 630 & 56.01 & 33.04 & 0.00 & 100.0 \\
\hline EP6 & Energy poverty 6 & $\begin{array}{l}\text { Non-renewable energy consumption (\% of total final energy } \\
\text { consumption) }\end{array}$ & WDI & 2000s-2015 & 630 & 50.10 & 27.67 & 2.71 & 94.45 \\
\hline Cap & Capital stock & $\begin{array}{l}\text { Percentage of capital stock to real GDP (at constant } 2011 \text { national } \\
\text { prices) }\end{array}$ & $\begin{array}{l}\text { PWT } \\
9.1\end{array}$ & 1970s-2017 & 720 & 346.1 & 131.5 & 126.9 & 799.9 \\
\hline $\mathrm{HC}$ & Human capital & Log of human capital index & $\begin{array}{l}\text { PWT } \\
9.1\end{array}$ & 1970s-2017 & 720 & 0.70 & 0.27 & 0.08 & 1.14 \\
\hline Trade & Trade openness & Trade (\% GDP) & WDI & $1960-2018$ & 719 & 67.65 & 26.46 & 20.72 & 175.8 \\
\hline FDI & FDI inflows & Foreign direct investment, net inflows ( $\%$ of GDP) & WDI & $1960-2018$ & 720 & 3.41 & 4.29 & -6.06 & 39.46 \\
\hline Income & Income level & Log of real GDP per capita & WDI & $1960-2018$ & 720 & 7.68 & 1.01 & 5.37 & 9.39 \\
\hline Internet & Internet usage & Individuals using the Internet (\% of population) & WDI & $2000 s-2018$ & 720 & 16.89 & 17.53 & 0.12 & 74.29 \\
\hline Inst & Institutional quality & Average of 6 institutional indicators & WGI & 2002-2018 & 720 & -0.48 & 0.47 & -1.70 & 0.88 \\
\hline FD & $\begin{array}{l}\text { Financial } \\
\text { development }\end{array}$ & Overall financial development index & FD-IMF & $1980-2017$ & 704 & 0.22 & 0.13 & 0.04 & 0.72 \\
\hline SE & Shadow economy & Shadow economy (\% GDP) & IMF & $1991-2015$ & 630 & 37.34 & 10.53 & 17.89 & 69.08 \\
\hline
\end{tabular}

PWT 9.1., Penn World Table version 9.1.; WDI, the World Development Indicators database (World Bank); WGI, the Worldwide Governance Indicators database (World Bank); FD-IMF, the financial development database from the IMF. Six institutional indicators from the WGI are control of corruption, government effectiveness, rule of law, regulatory quality, voice and accountability, and political stability and absence of violence. The shadow economy is calculated by Medina and Schneider (2018) and freely collected from the IMF

Table 2 Unconditional correlations between main variables

\begin{tabular}{|c|c|c|c|c|c|c|c|c|c|c|c|c|}
\hline Correlation & TFP & TFPc & EP1 & EP2 & EP3 & EP4 & EP5 & EP6 & Cap & $\mathrm{HC}$ & Trade & FDI \\
\hline TFP & 1.000 & & & & & & & & & & & \\
\hline TFPc & 0.138 & 1.000 & & & & & & & & & & \\
\hline$p$ value & 0.000 & & & & & & & & & & & \\
\hline EP1 & -0.022 & -0.489 & 1.000 & & & & & & & & & \\
\hline$p$ value & 0.566 & 0.000 & & & & & & & & & & \\
\hline EP2 & -0.007 & -0.499 & 0.829 & 1.000 & & & & & & & & \\
\hline$p$ value & 0.847 & 0.000 & 0.000 & & & & & & & & & \\
\hline EP3 & -0.015 & -0.446 & 0.787 & 0.946 & 1.000 & & & & & & & \\
\hline$p$ value & 0.701 & 0.000 & 0.000 & 0.000 & & & & & & & & \\
\hline EP4 & 0.003 & -0.394 & 0.704 & 0.925 & 0.820 & 1.000 & & & & & & \\
\hline$p$ value & 0.928 & 0.000 & 0.000 & 0.000 & 0.000 & & & & & & & \\
\hline EP5 & 0.260 & 0.180 & -0.188 & -0.152 & -0.131 & -0.128 & 1.000 & & & & & \\
\hline$p$ value & 0.000 & 0.000 & 0.000 & 0.000 & 0.001 & 0.001 & & & & & & \\
\hline EP6 & 0.113 & 0.460 & -0.833 & -0.729 & -0.727 & -0.615 & 0.423 & 1.000 & & & & \\
\hline$p$ value & 0.004 & 0.000 & 0.000 & 0.000 & 0.000 & 0.000 & 0.000 & & & & & \\
\hline Cap & -0.319 & -0.236 & -0.123 & -0.056 & -0.084 & -0.028 & 0.173 & 0.154 & 1.000 & & & \\
\hline$p$ value & 0.000 & 0.000 & 0.001 & 0.132 & 0.028 & 0.457 & 0.000 & 0.000 & & & & \\
\hline $\mathrm{HC}$ & -0.038 & 0.391 & -0.723 & -0.806 & -0.731 & -0.723 & 0.081 & 0.674 & 0.071 & 1.000 & & \\
\hline$p$ value & 0.310 & 0.000 & 0.000 & 0.000 & 0.000 & 0.000 & 0.042 & 0.000 & 0.057 & & & \\
\hline Trade & -0.036 & -0.008 & -0.060 & -0.025 & 0.034 & -0.084 & 0.073 & 0.130 & 0.244 & 0.051 & 1.000 & \\
\hline$p$ value & 0.336 & 0.831 & 0.122 & 0.507 & 0.374 & 0.024 & 0.066 & 0.001 & 0.000 & 0.174 & & \\
\hline FDI & 0.028 & -0.088 & 0.027 & 0.104 & 0.142 & 0.104 & -0.068 & -0.006 & -0.092 & -0.121 & 0.315 & 1.000 \\
\hline$p$ value & 0.448 & 0.018 & 0.492 & 0.005 & 0.000 & 0.005 & 0.086 & 0.890 & 0.014 & 0.001 & 0.000 & \\
\hline
\end{tabular}




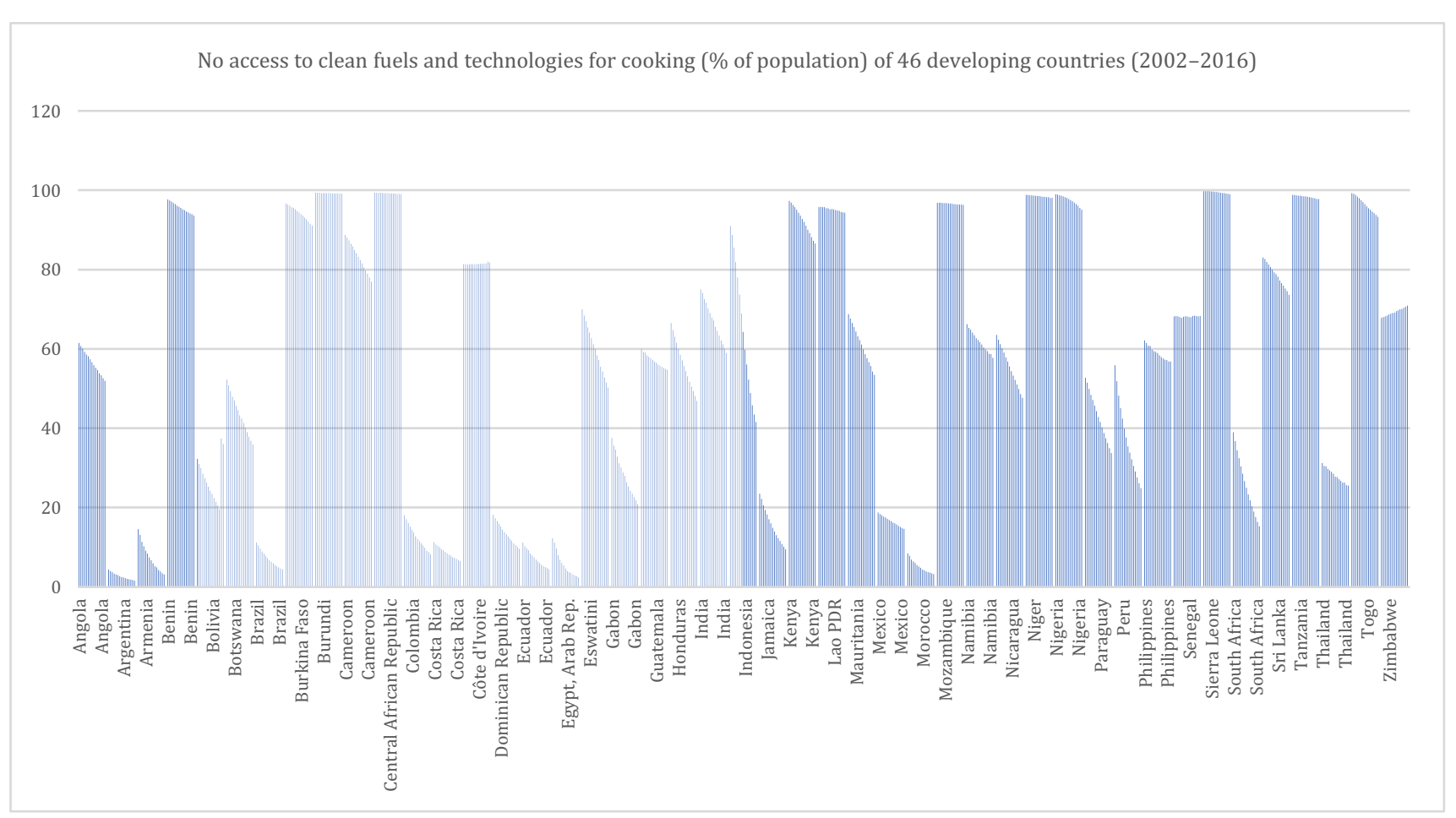

(a)

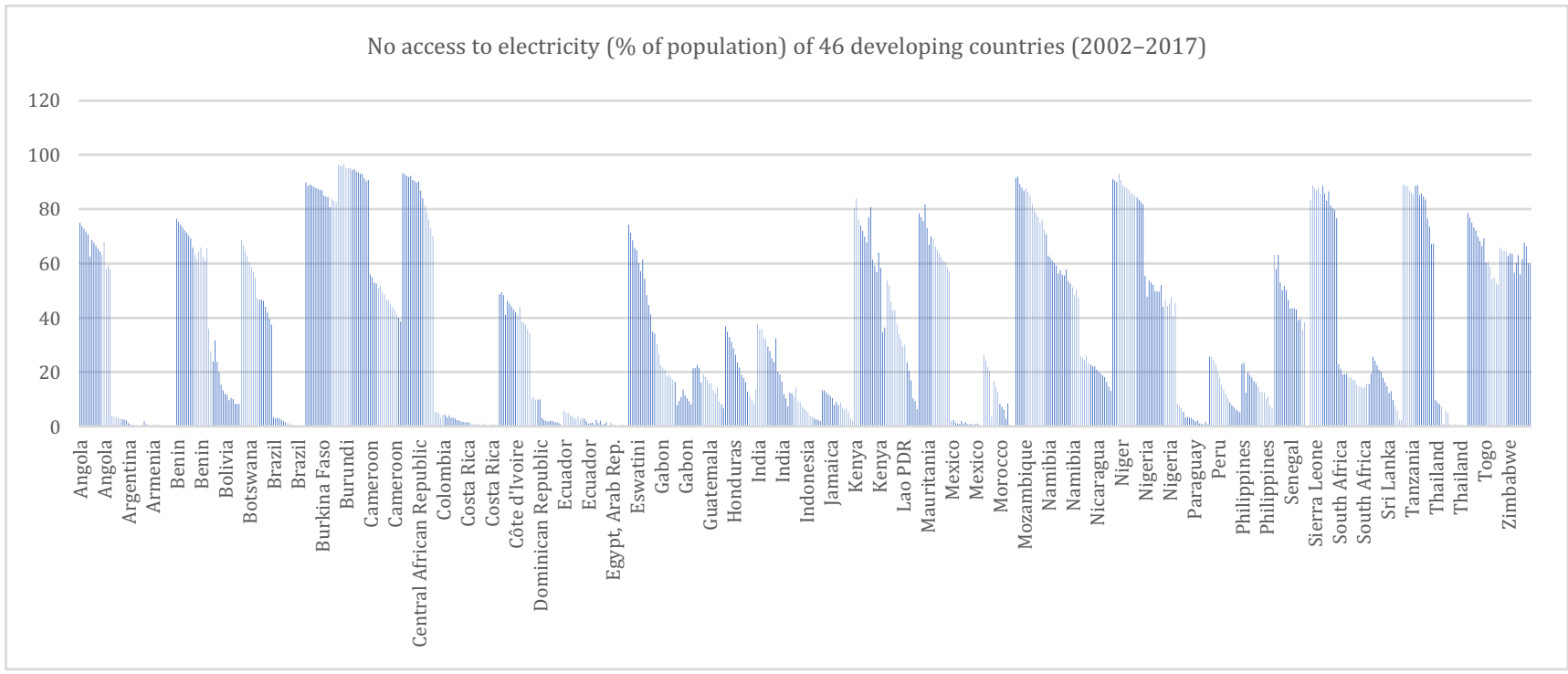

(b)

Fig. 1 The energy poverty in 45 developing countries. a No access to clean fuels and technologies. b No access to electricity

industrialisation and urbanisation in developing countries (Canh et al. 2020a) increases productivity besides capital accumulation and human capital (Chen and SantosPaulino 2013). In reverse, we can argue that renewable electricity would be a factor in reducing productivity in developing countries. This finding is likely opposite to the finding in several previous studies. For instance, Rath et al. (2019) find that fossil energy consumption has a negative impact on TFP growth in a sample of 36 countries, while renewable energy consumption has a positive 


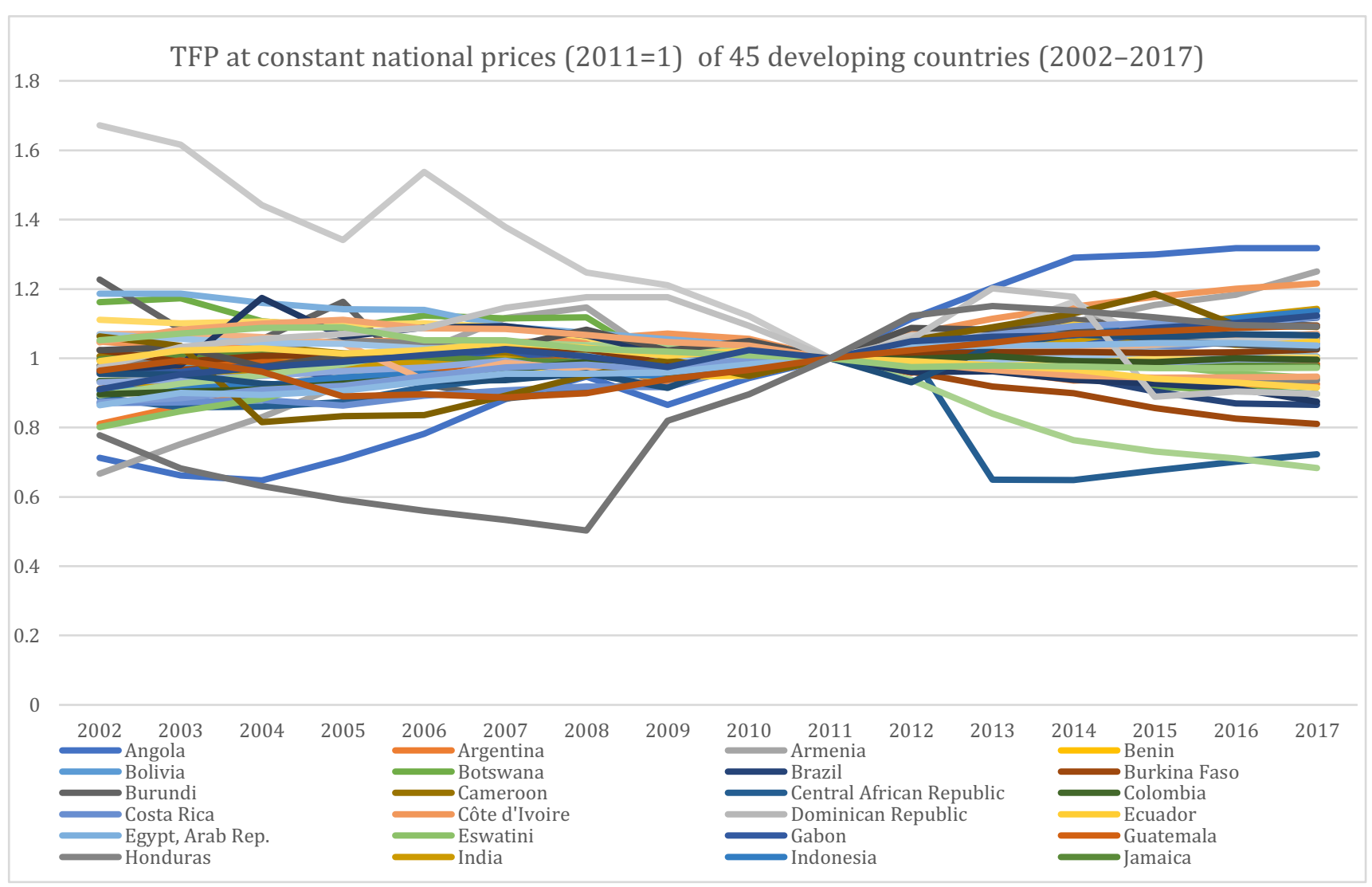

(a)

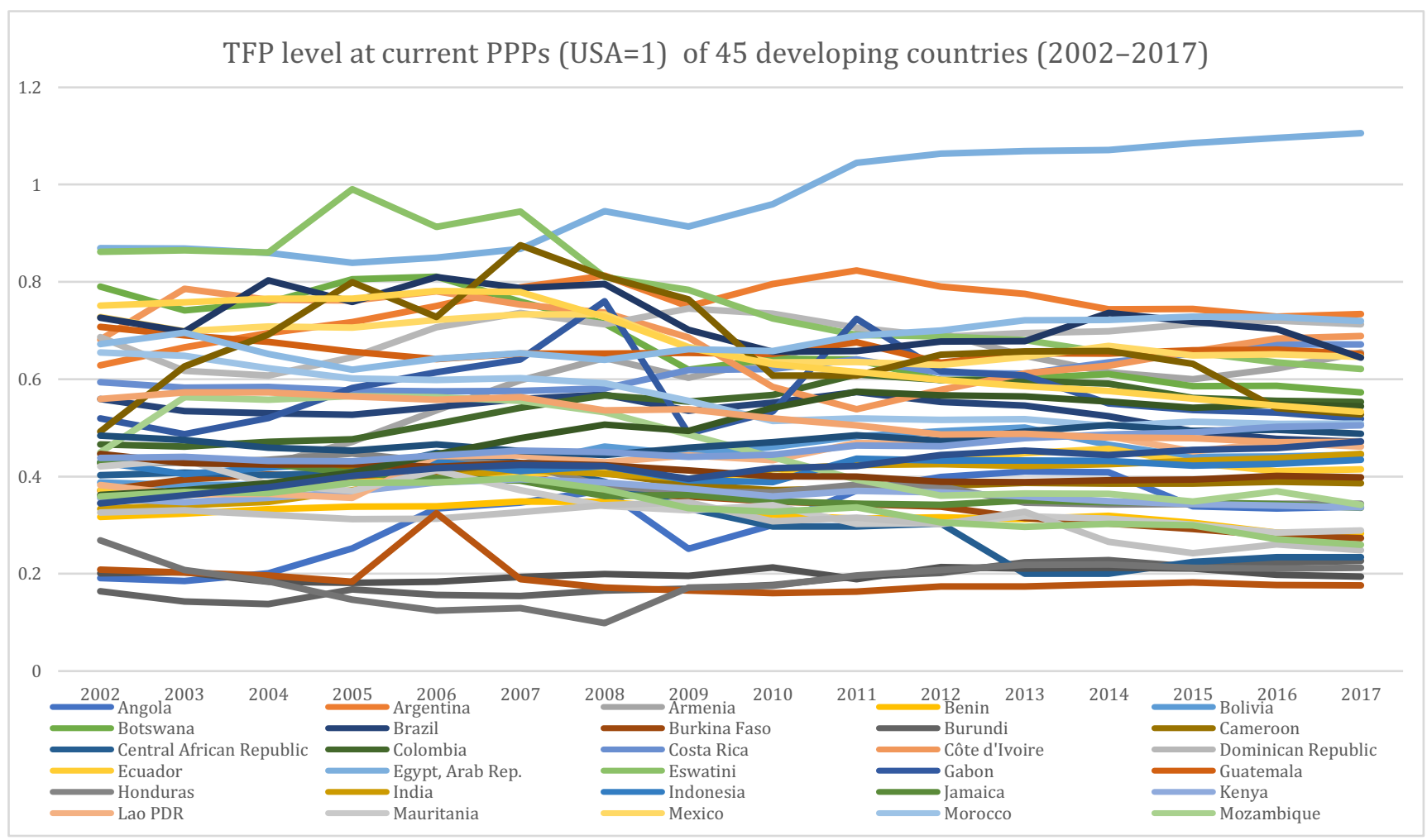

(b)

Fig. 2 The TFP in 45 developing countries. a TFP level. b TFP convergence 
Table 3 Non-Granger causality tests

\begin{tabular}{|c|c|c|c|c|c|c|c|c|}
\hline \multirow[t]{2}{*}{ Energy poverty } & \multicolumn{2}{|c|}{$\begin{array}{l}\text { Energy poverty does } \\
\text { not Granger-cause } \\
\text { TFP level (TFP) }\end{array}$} & \multicolumn{2}{|c|}{$\begin{array}{l}\text { TFP level does not } \\
\text { Granger-cause ener- } \\
\text { gy poverty }\end{array}$} & \multicolumn{2}{|c|}{$\begin{array}{l}\text { Energy poverty } \\
\text { does not Granger- } \\
\text { cause TFP conver- } \\
\text { gence (TFPc) }\end{array}$} & \multicolumn{2}{|c|}{$\begin{array}{l}\text { TFP convergence } \\
\text { does not Granger- } \\
\text { cause energy pov- } \\
\text { erty }\end{array}$} \\
\hline & Z-bar & $p$ value & Z-bar & $p$ value & & & & \\
\hline EP1 & $21.37 * * *$ & 0.000 & $2.074 * *$ & 0.038 & $12.86^{* * * *}$ & 0.000 & -1.637 & 0.101 \\
\hline EP2 & $21.84 * * *$ & 0.000 & $10.71 * * *$ & 0.000 & $7.273 * * *$ & 0.000 & $7.708 * * *$ & 0.000 \\
\hline EP3 & $6.734 * * *$ & 0.000 & $13.90 * * *$ & 0.000 & $3.069 * * *$ & 0.002 & $8.478 * * *$ & 0.000 \\
\hline EP4 & $17.43 * * *$ & 0.000 & $8.319 * * *$ & 0.000 & $6.616 * * *$ & 0.000 & $11.16^{* * *}$ & 0.000 \\
\hline EP5 & $10.22 * * *$ & 0.000 & $7.156^{* * *}$ & 0.000 & $4.920 * * *$ & 0.000 & $8.367 * * *$ & 0.000 \\
\hline EP6 & $10.02 * * *$ & 0.000 & $4.929 * * *$ & 0.000 & $11.52 * * *$ & 0.000 & $6.585 * * *$ & 0.000 \\
\hline
\end{tabular}

In non-Granger causality tests (Dumitrescu and Hurlin (2012)): H0: $X$ does not Granger-cause $Y ; \mathrm{H} 1: X$ does Granger-cause $Y$ for at least one panelvar (country). *, **, and *** are significant levels at $10 \%, 5 \%$, and $1 \%$, respectively impact. However, the sample observed in the study of Rath et al. (2019) is mostly advanced economies, ${ }^{7}$ while our sample is that of developing countries. Thus, our results provide new evidence on the negative impacts of renewable energy consumption/production on productivity in developing countries, which may be due to the low level, inefficiency, and high costs of the renewable energy sector in developing countries (Adenikinju 1998; Moghaddasi and Pour 2016).

Overall, the conclusion that can be drawn is that EP, when considered from the aspect of basic needs such as no access to clean fuels and technologies for cooking, or no access to electricity, would reduce TFP level/convergence in developing countries, while non-renewable electricity consumption/ production would increase TFP level/convergence.

\section{Effects of energy poverty on TFP level/convergence: transmission channels}

The channels of EP effects on the TFP level and TFP convergence are examined through the estimates for system Eqs. (3), (4), and (5), respectively. The results from 3SLS are presented in Tables 5, 6, and 7, and the results from 2SLS (robustness testing) are reported in Tables A4, A5, and A6, Appendix, showing consistent findings.

Table 5 shows the results for system Eq. (3), which investigates the impacts of EP on human capital accumulation and then the impact of human capital accumulation on productivity. The observations show that EP1, EP2, EP3, and EP4 have significant negative impacts on human capital, while EP5 and EP6 have significant positive

\footnotetext{
${ }^{7}$ The advanced economies are Argentina, Australia, Austria, Belgium, Brazil, Canada, Chile, China, Colombia, Denmark, Egypt, Finland, France, Greece, India, Indonesia, Iran, Italy, Japan, Malaysia, Mexico, Morocco, Netherlands, New Zealand, Nigeria, Norway, Peru, Spain, Sweden, Switzerland, Thailand, Tunisia, Turkey, UK, USA, and Venezuela.
}

impacts. Conversely, human capital has a significant positive impact on TFP level/convergence. The results mean that no access to clean fuels and technologies/no access to electricity (in the total, rural, or urban populations) has decreasing effects on human capital accumulation, which then convert into negative impacts on TFP level/ convergence as documented in Table 4. Meanwhile, EP5 and EP6 (non-renewable electricity production and consumption, respectively) appear to have significant positive impacts on human capital, radically transformed into positive impacts on TFP level/productivity as documented in Table 4. In general, the results in Table 5 confirm our second hypothesis that the effects of EP on productivity would be transmitted through the channel of human capital.

Standard errors are in brackets; *,**, and *** denote significance levels at $10 \%, 5 \%$, and $1 \%$, respectively

The investigation into Internet usage as a channel of EP effects on TFP level/convergence is carried out as reflected in system Eq. (4). The results are presented in Table 6, which provides the same evidence as in the case of human capital. EP1, EP2, EP3, and EP4 have significant negative impacts on Internet usage, while Internet usage appears to have significant positive impacts on TFP level/convergence. That is, EP from the aspects of no access to clean fuels and technologies for cooking, or no access to electricity, would reduce technology development, which is then transmitted negatively to TFP level/convergence as documented in Table 4. Meanwhile, EP5 and EP6 have positive impacts on Internet usage (statistically insignificant for EP5 and statistically significant for EP6), subsequently transmitted positively to TFP level/convergence. Overall, the evidence in Table 6 is similar to the evidence in Table 5 that effects of EP on TFP in developing countries can be transmitted through the channel of technology development. Hence, the third hypothesis is also confirmed. 


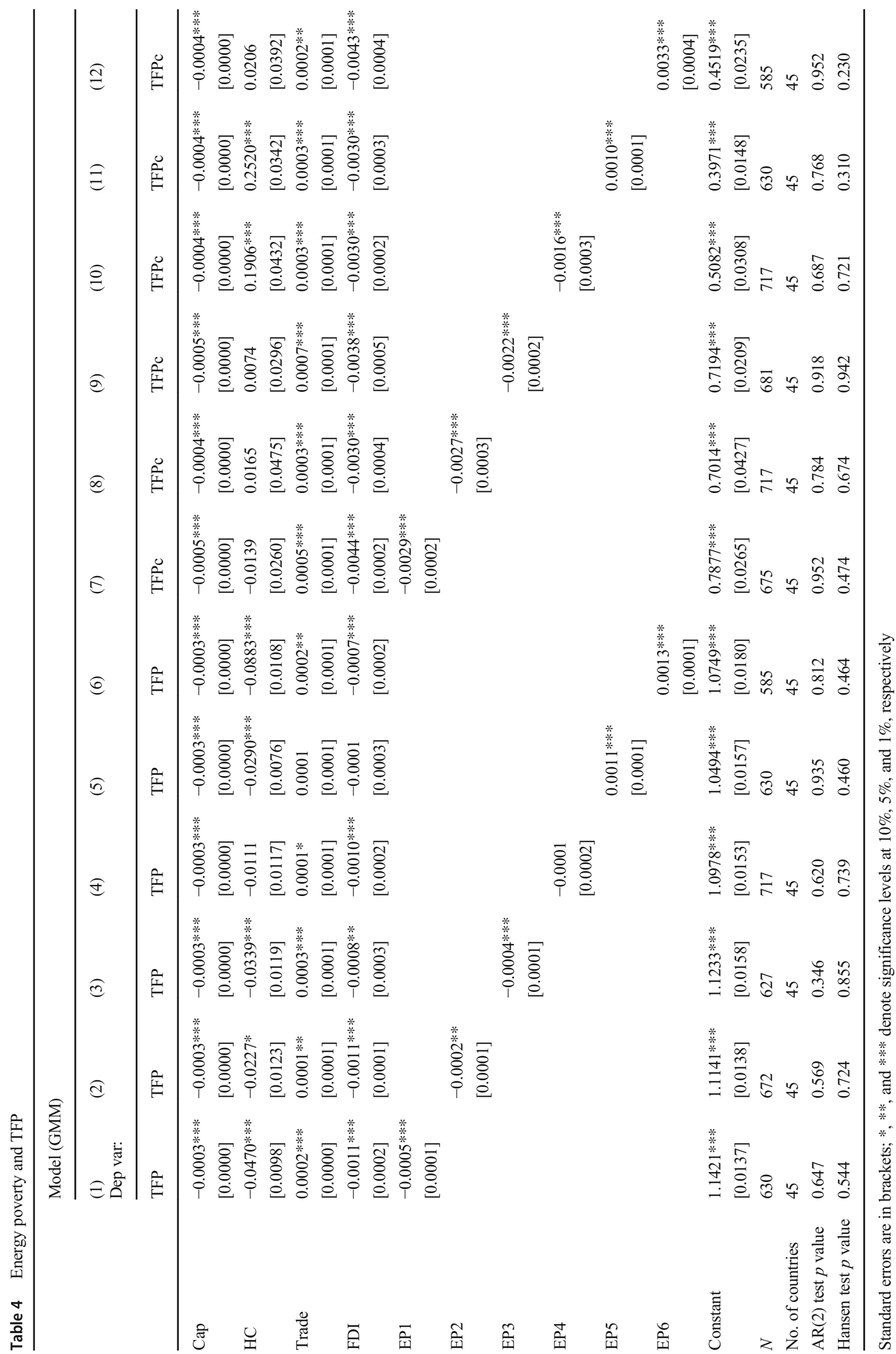




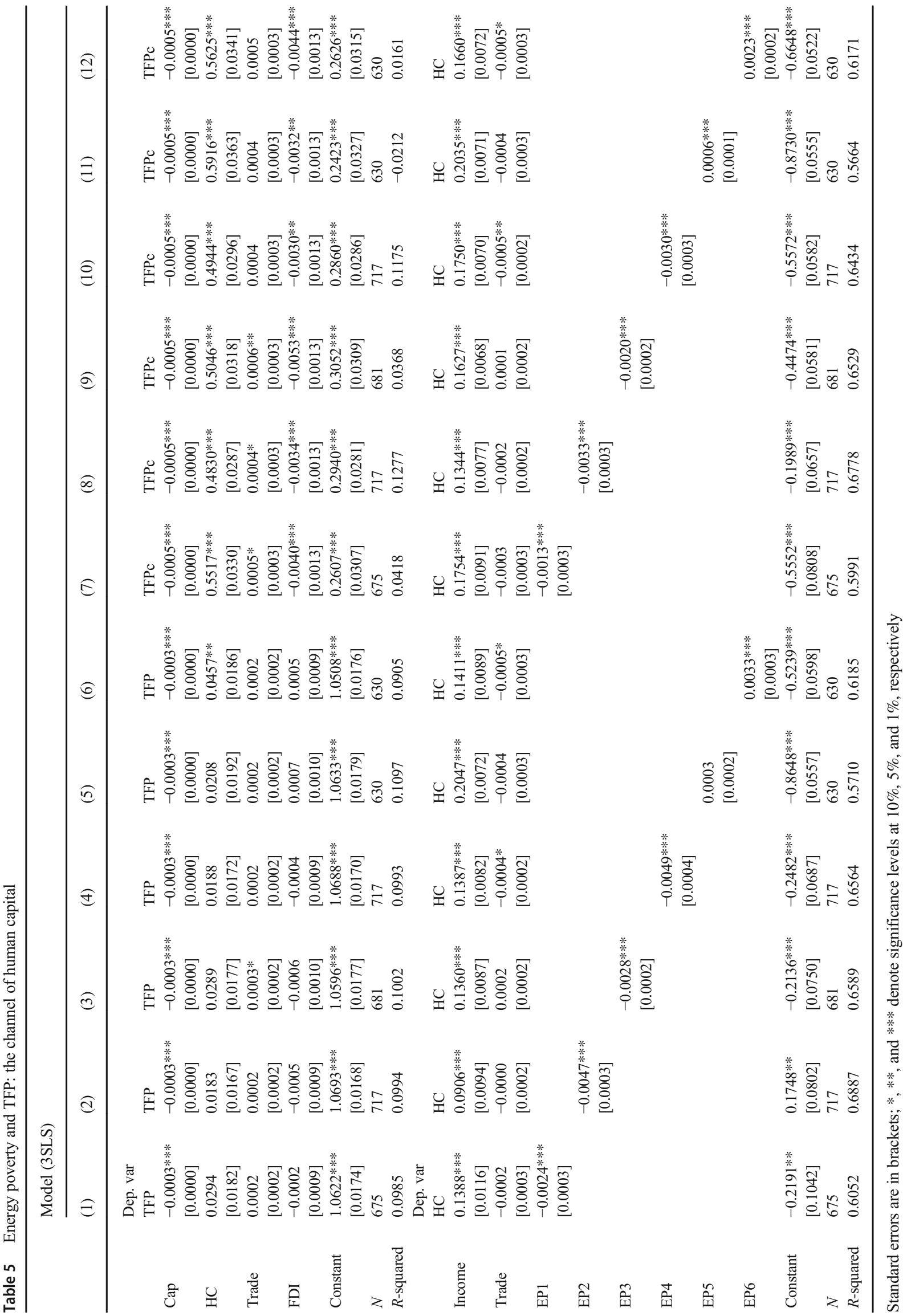




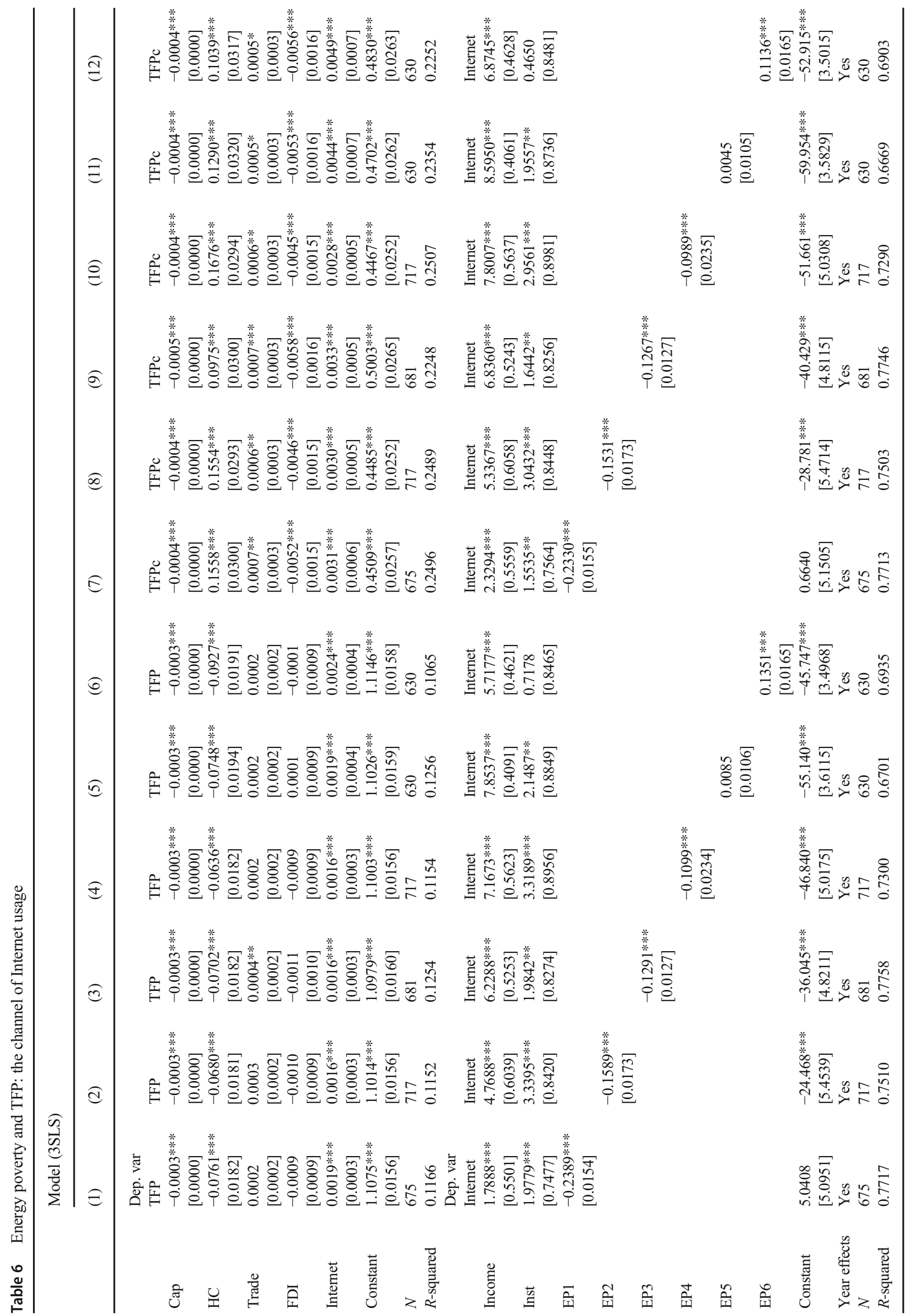




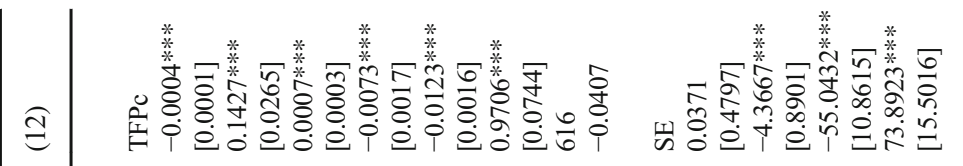

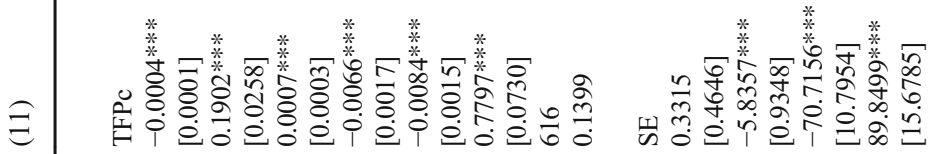

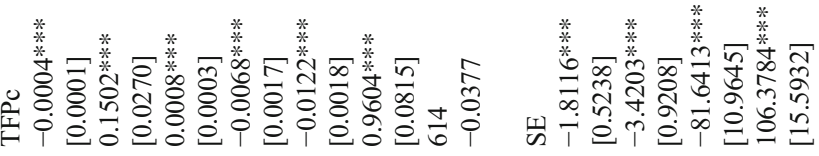

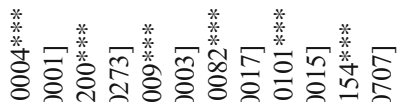

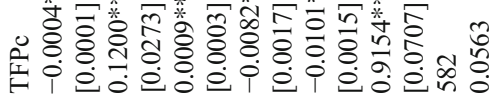

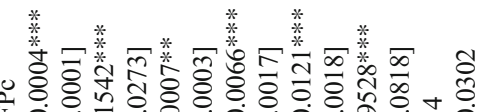

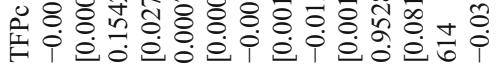

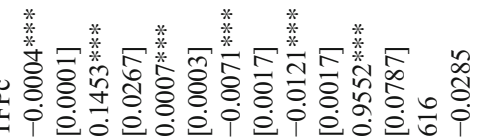

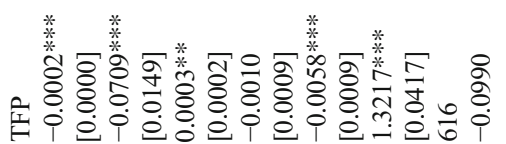

6

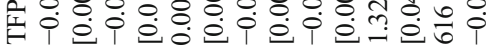

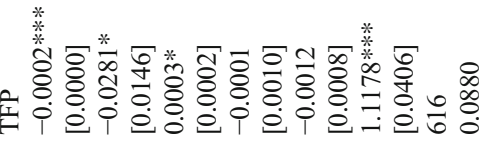

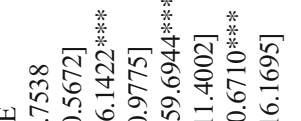

س

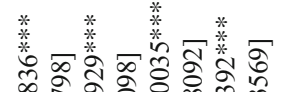

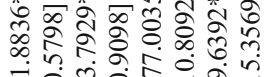

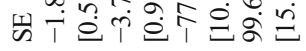

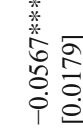

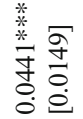

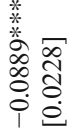

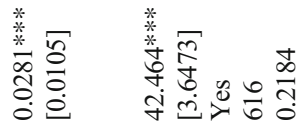

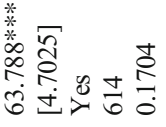

*

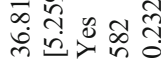

类帝

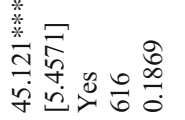

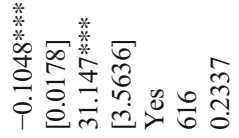

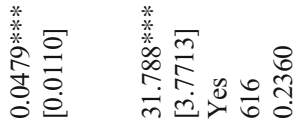

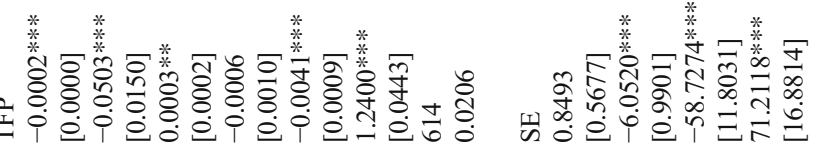

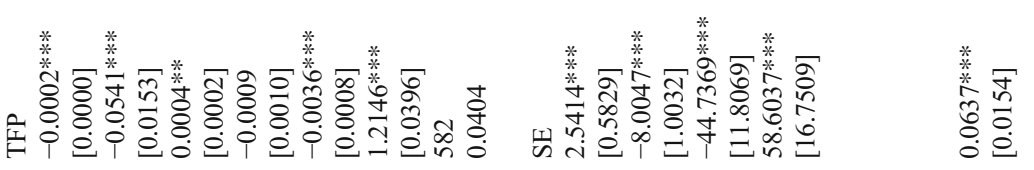

范

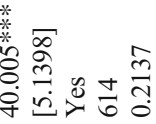

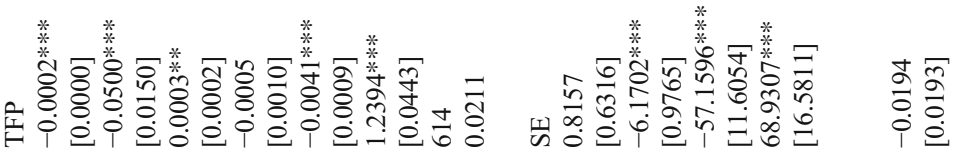

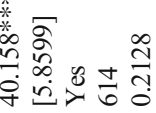

蛋绐

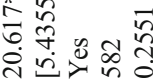

(ิ)

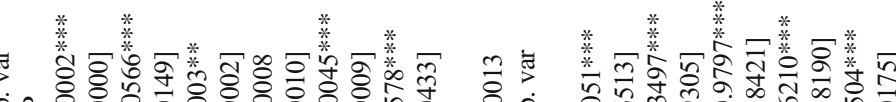

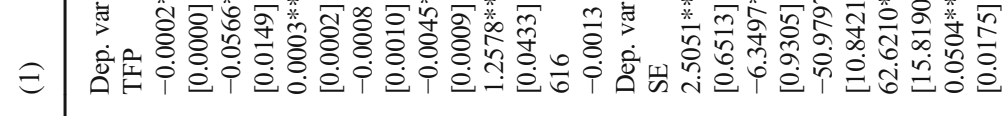

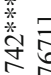

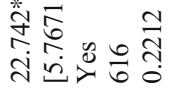

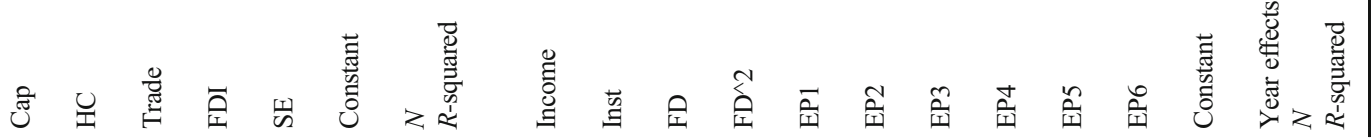


Lastly, the effects of EP on productivity through the channel of the shadow economy are estimated and realised through system Eq. (5). The results in Table 7 show that no access to clean fuels and technologies for cooking (EP1), no access to electricity in the rural population (EP3), and non-renewable electricity production (EP5) have significant positive impacts on the shadow economy, while non-renewable electricity consumption has a significant negative impact on the shadow economy. No access to electricity in the total population and no access to electricity in the urban population have negative but insignificant impacts. In all cases, the shadow economy appears to have significant negative impacts on TFP level/convergence. That is, the negative impacts of EP on TFP level/convergence in developing countries as found in Table 4 are transmitted through the increasing effects of EP on informal economic activities, which then leads to a reduction in productivity.

Standard errors are in brackets; *, **, and *** denote significance levels at $10 \%, 5 \%$, and $1 \%$, respectively

\section{Conclusion}

This study contributes to the literature by shedding light on two important topics: EP and productivity. The study examines the impact of EP on TFP level/convergence in 45 developing countries from 2002 to 2017. Notably, the channels of EP effects on productivity through human capital, Internet usage, and the shadow economy are analysed using system equation estimates.

The empirical results are threefold: (i) the non-Granger causality tests show the mutual causalities between each of the six proxies of EP and TFP level/convergence; (ii) there are significant negative impacts of four out of the six proxies of EP on TFP level/convergence; (iii) the influence of EP on TFP level/convergence is empirically proven to be transmitted through three main channels, namely human capital accumulation, Internet usage, and the shadow economy.

The study results imply that EP is one of the causes of, and a precursor to, low productivity in developing countries, since it has adverse consequences for human development and technology development while increasing informal economic activities. The findings of this study add to the literature on the economic consequences of EP in two ways. The study demonstrates a new economic consequence of EP that of a negative impact on labour productivity. In particular, the study implies that the negative impact of EP on economic development (e.g. see Chevalier and Ouédraogo (2009)) might be explained through the channel of labour productivity; that is, EP causes a reduction in labour productivity leading to a decrease in economic growth. Interestingly, the study finds that the negative impact of EP on labour productivity appears to be transmitted through the channels of human capital, technology development, and the shadow economy, which has significant policy implications.

Our results also suggest that the use of non-renewable electricity as a way of addressing EP can be effective in improving productivity, but due caution is urged since it has side effects on the environment. Lastly, it is worth noting that the influence of EP on productivity may be affected by the level of capital intensity. On the other hand, investment in infrastructure, especially in the energy sector, is an important factor in eliminating EP. Therefore, there may be interesting relationships between capital intensity, EP, and productivity in developing countries, which need further study.

Supplementary Information The online version contains supplementary material available at https://doi.org/10.1007/s11356-021-14614-x.

Acknowledgements The authors are thankful for the helpful comments and suggestions from the Editors and two anonymous reviewers from the Environmental Science and Pollution Research journal.

Availability of data and materials The data will be provided by the corresponding author under reasonable requests.

Author contribution Canh Phuc Nguyen: conceptualisation, methodology, data curation, validation, formal analysis, writing - original draft preparation, writing - reviewing and editing; Thanh Dinh Su: methodology, validation, writing - reviewing and editing

Funding This study is funded by the University of Economics Ho Chi Minh City, Ho Chi Minh, 700000, Vietnam.

\section{Declarations}

Ethics approval and consent to participate None.

Consent for publication None.

Competing interests The authors declare no competing interests.

\section{References}

Adenikinju AF (1998) Productivity growth and energy consumption in the Nigerian manufacturing sector: a panel data analysis. Energy Policy 26:199-205. https://doi.org/10.1016/S0301-4215(97)00098-

Adetutu MO, Ajayi V (2020) The impact of domestic and foreign R\&D on agricultural productivity in sub-Saharan Africa. World Dev 125: 104690. https://doi.org/10.1016/j.worlddev.2019.104690

Ahsan H, Haque ME (2017) Threshold effects of human capital: schooling and economic growth. Econ Lett 156:48-52. https://doi.org/10. 1016/j.econlet.2017.04.014

Amin A, Liu Y, Yu J, Chandio AA, Rasool SF, Luo J, Zaman S (2020) How does energy poverty affect economic development? A panel data analysis of South Asian countries. Environ Sci Pollut Res 27: 31623-31635. https://doi.org/10.1007/s11356-020-09173-6 
Anderson TW, Hsiao C (1982) Formulation and estimation of dynamic models using panel data. J Econ 18:47-82

Arellano M, Bond S (1991) Some tests of specification for panel data: Monte Carlo evidence and an application to employment equations. Rev Econ Stud 58:277-297

Arellano M, Bover O (1995) Another look at the instrumental variable estimation of error-components models. J Econ 68:29-51

Ashraf A, Herzer D, Nunnenkamp P (2016) The effects of Greenfield FDI and cross-border M\&As on total factor productivity. World Econ 39:1728-1755

Awaworyi Churchill S, Smyth R (2020) Ethnic diversity, energy poverty and the mediating role of trust: evidence from household panel data for Australia. Energy Econ 86:104663. https://doi.org/10.1016/j. eneco.2020.104663

Awaworyi Churchill S, Smyth R, Farrell L (2020) Fuel poverty and subjective wellbeing. Energy Econ 86:104650. https://doi.org/10. 1016/j.eneco.2019.104650

Bai C, Du K, Yu Y, Feng C (2019) Understanding the trend of total factor carbon productivity in the world: insights from convergence analysis. Energy Econ 81:698-708. https://doi.org/10.1016/j.eneco.2019. 05.004

Baum CF, Lööf H, Nabavi P (2018) Innovation strategies, external knowledge and productivity growth. Ind Innov:1-20 doi:https:// doi.org/10.1080/13662716.2018.1499502, 26, 348, 367

Beilock R, Dimitrova DV (2003) An exploratory model of inter-country Internet diffusion. Telecommun Policy 27:237-252

Belsley DA (1988) Two-or three-stage least squares. Computer Sci Econ Manag 1:21-30

Blanchard EJ, Olney WW (2017) Globalization and human capital investment: export composition drives educational attainment. J Int Econ 106:165-183. https://doi.org/10.1016/j.jinteco.2017.03.004

Blundell R, Bond S (1998) Initial conditions and moment restrictions in dynamic panel data models. J Econ 87:115-143

Bouzarovski S (2014) Energy poverty in the European Union: landscapes of vulnerability. Wiley Interdisciplinary Rev: Energy Environ 3: 276-289

Bresnahan L, Coxhead I, Foltz J, Mogues T (2016) Does freer trade really lead to productivity growth? Evidence from Africa. World Dev 86: 18-29. https://doi.org/10.1016/j.worlddev.2016.05.007

Canh PN, Dinh Thanh S (2020) Exports and the shadow economy: nonlinear effects. J Int Trade Econ Dev:1-26

Canh NP, Thanh SD (2020) Financial development and the shadow economy: a multi-dimensional analysis. Econ Anal Policy 67:37-54

Canh NP, Thanh SD, Nasir MA (2020a) Nexus between financial development \& energy intensity: two sides of a coin? J Environ Manag 270:110902

Canh PN, Schinckus C, Dinh Thanh S (2020b) What are the drivers of shadow economy? A further evidence of economic integration and institutional quality. The Journal of International Trade \& Economic Development:1-21

Chancellor W, Abbott M (2015) The Australian construction industry: is the shadow economy distorting productivity? Constr Manag Econ 33:176-186

Chang C-F, Wang P, Liu J-T (2016) Knowledge spillovers, human capital and productivity. J Macroecon 47:214-232. https://doi.org/10. 1016/j.jmacro.2015.11.003

Chen S, Santos-Paulino AU (2013) Energy consumption restricted productivity re-estimates and industrial sustainability analysis in postreform. China Energy Policy 57:52-60. https://doi.org/10.1016/j. enpol.2012.08.060

Chevalier J-M, Ouédraogo NS (2009) Energy poverty and economic development. In: Chevalier J-M (ed) The new energy crisis: climate, economics and geopolitics. Palgrave Macmillan UK, London, pp 115-144. https://doi.org/10.1057/9780230242234 5

d'Agostino G, Scarlato M (2019) Knowledge externalities, innovation and growth in European countries: the role of institutions. Econ
Innov New Technol 28:82-99. https://doi.org/10.1080/10438599. 2018.1429536

Defever F, Imbruno M, Kneller R (2020) Trade liberalization, input intermediaries and firm productivity: evidence from China. J Int Econ 126:103329. https://doi.org/10.1016/j.jinteco.2020.103329

Demir F, Duan Y (2018) Bilateral FDI flows, productivity growth, and convergence: the north vs. the south. World Dev 101:235-249. https://doi.org/10.1016/j.worlddev.2017.08.006

Dumitrescu E-I, Hurlin C (2012) Testing for Granger non-causality in heterogeneous panels. Econ Model 29:1450-1460

Edquist H, Henrekson M (2017) Do R\&D and ICT affect total factor productivity growth differently? Telecommun Policy 41:106-119. https://doi.org/10.1016/j.telpol.2016.11.010

Engelbrecht H-J (2002) Human capital and international knowledge spillovers in TFP growth of a sample of developing countries: an exploration of alternative approaches. Appl Econ 34:831-841. https://doi. org/10.1080/00036840110061947

Feenstra RC, Inklaar R, Timmer MP (2015) The next generation of the Penn World Table. Am Econ Rev 105:3150-3182. https://doi.org/ 10.1257/aer.20130954

Figal Garone L, López Villalba PA, Maffioli A, Ruzzier CA (2020) Firmlevel productivity in Latin America and the Caribbean. Res Econ 74: 186-192. https://doi.org/10.1016/j.rie.2020.04.004

Fleisher B, Li H, Zhao MQ (2010) Human capital, economic growth, and regional inequality in China. J Dev Econ 92:215-231

Giannini Pereira M, Vasconcelos Freitas MA, da Silva NF (2011) The challenge of energy poverty: Brazilian case study. Energy Policy 39: 167-175. https://doi.org/10.1016/j.enpol.2010.09.025

Glawe L, Wagner H (2019) China in the middle-income trap? China Econ Rev 60:101264. https://doi.org/10.1016/j.chieco.2019.01.003

González-Eguino M (2015) Energy poverty: an overview. Renew Sust Energ Rev 47:377-385. https://doi.org/10.1016/j.rser.2015.03.013

Goyens M (2020) COVID-19 means tackling energy poverty is more urgent than ever. https://www.euractiv.com/section/energy/ opinion/covid-19-means-tackling-energy-poverty-is-more-urgentthan-ever/. Accessed 04 August 2020

Groh S (2014) The role of energy in development processes - the energy poverty penalty: case study of Arequipa (Peru). Energy Sustain Dev 18:83-99. https://doi.org/10.1016/j.esd.2013.12.002

Hanna K, Sambrook P, Armfield J, Brennan D (2017) Internet use, online information seeking and knowledge among third molar patients attending public dental services. Aust Dent J 62:323-330

Hein E (2012) "Financialization," distribution, capital accumulation, and productivity growth in a post-Kaleckian model. J Post Keynesian Econ 34:475-496

Howitt P, Aghion P (1998) Capital accumulation and innovation as complementary factors in long-run growth. J Econ Growth 3:111-130

Jain G (2010) Alleviating energy poverty: Indian experience. Regulatory Studies and Governance Division The Energy and Resources Institute, http://www indiaenergycongress in/montreal/library/pdf/ 319 pdf,(1110 2015)

Jones CI, Romer PM (2010) The new Kaldor facts: ideas, institutions, population, and human capital. Am Econ J Macroecon 2:224-245

Kaygusuz K (2010) Energy services and energy poverty for rural regions. Energy Sources Part B: Econ Planning Policy 5:424-433. https:// doi.org/10.1080/15567240802458716

Kaygusuz K (2011) Energy services and energy poverty for sustainable rural development. Renew Sust Energ Rev 15:936-947. https://doi. org/10.1016/j.rser.2010.11.003

Khor N, Pang L, Liu C, Chang F, Mo D, Loyalka P, Rozelle S (2016) China's looming human capital crisis: upper secondary educational attainment rates and the middle-income trap. China Q 228:905-926

Kose T (2019) Energy poverty and health: the Turkish case. Energy Sources Part B: Econ Planning Policy 14:201-213. https://doi.org/ 10.1080/15567249.2019.1653406 
Kripfganz S (2017) Sequential (two-stage) estimation of linear panel-data models. In: German Stata Users; Group Meetings, vol 03 Stata Users Group

Lapatinas A (2019) The effect of the Internet on economic sophistication: an empirical analysis. Econ Lett 174:35-38. https://doi.org/10.1016/ j.econlet.2018.10.013

Le T-H, Nguyen CP (2019) Is energy security a driver for economic growth. Evidence Global Sample Energy policy 129:436-451

Li C, Tanna S (2019) The impact of foreign direct investment on productivity: new evidence for developing countries. Econ Model 80:453466. https://doi.org/10.1016/j.econmod.2018.11.028

Llorca M, Rodriguez-Alvarez A, Jamasb T (2020) Objective vs. subjective fuel poverty and self-assessed health. Energy Econ 87:104736. https://doi.org/10.1016/j.eneco.2020.104736

Manlove J, Whitacre B (2019) Understanding the trend to mobile-only internet connections: a decomposition analysis. Telecommun Policy 43:76-87. https://doi.org/10.1016/j.telpol.2018.03.012

Männasoo K, Hein H, Ruubel R (2018) The contributions of human capital, $R \& D$ spending and convergence to total factor productivity growth. Reg Stud 52:1598-1611. https://doi.org/10.1080/ 00343404.2018 .1445848

Mastromarco C, Zago A (2012) On modeling the determinants of TFP growth. Struct Chang Econ Dyn 23:373-382. https://doi.org/10. 1016/j.strueco.2012.04.001

Medina L, Schneider F (2018) Shadow economies around the world: what did we learn over the last 20 years? IMF Working Paper No. $18 / 17$

Miller SM, Upadhyay MP (2000) The effects of openness, trade orientation, and human capital on total factor productivity. J Dev Econ 63: 399-423. https://doi.org/10.1016/S0304-3878(00)00112-7

Moghaddasi R, Pour AA (2016) Energy consumption and total factor productivity growth in Iranian agriculture. Energy Rep 2:218-220. https://doi.org/10.1016/j.egyr.2016.08.004

Monyei CG, Adewumi AO (2017) Demand side management potentials for mitigating energy poverty in South Africa. Energy Policy 111: 298-311. https://doi.org/10.1016/j.enpol.2017.09.039

Muller J (2009) Considering ICT use when energy access is not secured: a case study from rural South Africa. African Women \& ICTs, Investigating Technology, Gender and Empowerment, pp 33-43

Nguyen CP, Nasir MA (2021) An inquiry into the nexus between energy poverty and income inequality in the light of global evidence. Energy Econ 99:105289. https://doi.org/10.1016/j.eneco.2021. 105289

Okushima S (2016) Measuring energy poverty in Japan, 2004-2013. Energy Policy 98:557-564. https://doi.org/10.1016/j.enpol.2016. 09.005

Pachauri S, Spreng D (2011) Measuring and monitoring energy poverty. Energy Policy 39:7497-7504. https://doi.org/10.1016/j.enpol.2011. 07.008

Pachauri S, Mueller A, Kemmler A, Spreng D (2004) On measuring energy poverty in Indian households. World Dev 32:2083-2104. https://doi.org/10.1016/j.worlddev.2004.08.005
Papaioannou SK (2018) EU services liberalization and TFP growth: industry level evidence. Econ Lett 172:16-18. https://doi.org/10.1016/ j.econlet.2018.08.015

Pereira MG, Freitas MAV, da Silva NF (2010) Rural electrification and energy poverty: empirical evidences from Brazil. Renew Sust Energ Rev 14:1229-1240. https://doi.org/10.1016/j.rser.2009.12.013

Rath BN, Akram V, Bal DP, Mahalik MK (2019) Do fossil fuel and renewable energy consumption affect total factor productivity growth? Evidence from cross-country data with policy insights. Energy Policy 127:186-199. https://doi.org/10.1016/j.enpol.2018. 12.014

Rodriguez-Alvarez A, Orea L, Jamasb T (2019) Fuel poverty and wellbeing: a consumer theory and stochastic frontier approach. Energy Policy 131:22-32. https://doi.org/10.1016/j.enpol.2019.04.031

Roodman D (2006) How to do xtabond2: an introduction to difference and system GMM in Stata Center for Global Development Working Paper No. 103

Roodman D (2009) How to do xtabond2: an introduction to difference and system GMM in Stata The Stata. Journal 9:86-136

Sesan T (2012) Navigating the limitations of energy poverty: lessons from the promotion of improved cooking technologies in Kenya. Energy Policy 47:202-210. https://doi.org/10.1016/j.enpol.2012. 04.058

Sovacool BK (2012) The political economy of energy poverty: a review of key challenges. Energy Sustain Dev 16:272-282. https://doi.org/ 10.1016/j.esd.2012.05.006

Sovacool BK, Cooper C, Bazilian M, Johnson K, Zoppo D, Clarke S, Eidsness J, Crafton M, Velumail T, Raza HA (2012) What moves and works: broadening the consideration of energy poverty. Energy Policy 42:715-719. https://doi.org/10.1016/j.enpol.2011.12.007

Thomson H, Snell CJ, Liddell C (2016) Fuel poverty in the European Union: a concept in need of definition? People, Place \& Policy Online:5-24

Thomson H, Snell C, Bouzarovski S (2017) Health, well-being and energy poverty in Europe: a comparative study of 32 European countries. Int J Environ Res Public Health 14:584

UN (2019) The Sustainable Development Agenda. United Nations. https://www.un.org/sustainabledevelopment/development-agenda/. Accessed 02 Aug 2020

Viet Nguyen T, Simioni M, Le Van D (2019) Assessment of TFP change at provincial level in Vietnam: new evidence using Färe-Primont productivity index. Econ Anal Policy 64:329-345. https://doi.org/ 10.1016/j.eap.2019.09.007

Wang M, Arshed N, Munir M, Rasool SF, Lin W (2021) Investigation of the STIRPAT model of environmental quality: a case of nonlinear quantile panel data analysis. Environ Dev Sustain. https://doi.org/ 10.1007/s10668-020-01165-3

Zellner A, Theil H (1992) Three-stage least squares: simultaneous estimation of simultaneous equations. In: Henri Theil's Contributions to Economics and Econometrics. Springer, pp 147-178

Publisher's note Springer Nature remains neutral with regard to jurisdictional claims in published maps and institutional affiliations. 